\title{
Comparative Study on the Cytoprotective Effects of Activated Protein C Treatment in Nonsteatotic and Steatotic Livers under Ischemia-Reperfusion Injury
}

\author{
Akitoshi Matsuda, Naohisa Kuriyama, Hiroyuki Kato, Akihiro Tanemura, \\ Yasuhiro Murata, Yoshinori Azumi, Masashi Kishiwada, Shugo Mizuno, Masanobu Usui, \\ Hiroyuki Sakurai, and Shuji Isaji
}

Department of Hepatobiliary Pancreatic and Transplant Surgery, Mie University Graduate School of Medicine, Edobashi 2-174, Tsu, Mie 514-8507, Japan

Correspondence should be addressed to Naohisa Kuriyama; naokun@clin.medic.mie-u.ac.jp

Received 17 December 2014; Revised 15 April 2015; Accepted 17 April 2015

Academic Editor: Hartmut Jaeschke

Copyright (C) 2015 Akitoshi Matsuda et al. This is an open access article distributed under the Creative Commons Attribution License, which permits unrestricted use, distribution, and reproduction in any medium, provided the original work is properly cited.

Activated protein C (APC) has cytoprotective effects on liver ischemia-reperfusion injury (IRI). However, it is unclear whether APC is beneficial in steatotic liver IRI. We compared the cytoprotective effects of APC in nonsteatotic and steatotic liver IRI. Methods. Mice fed either normal diets (ND mice) or high fat diets (HF mice), were treated with APC or saline (control) and were performed 60 min partial IRI. Moreover, primary steatotic hepatocytes were either untreated or treated with APC and then incubated with $\mathrm{H}_{2} \mathrm{O}_{2}$. Results. APC significantly reduced serum transaminase levels and the inflammatory cells infiltration compared with control at $4 \mathrm{~h}$ in ND mice and at $24 \mathrm{~h}$ in HF mice. APC inhibited sinusoidal endothelial injury in ND mice, but not in HF mice. In contrast, APC activated adenosine monophosphate-activated protein kinase (AMPK) phosphorylation in HF mice, but not in ND mice. In the in vitro study, APC significantly increased AMPK phosphorylation, ATP concentration, and survival rates of hepatocytes compared with control. Conclusion. During IRI in normal liver, APC attenuated initial damage by inhibiting inflammatory cell infiltration and sinusoidal endothelial injury, but not in steatotic liver. However, in steatotic liver, APC might attenuate late damage via activation of AMPK.

\section{Introduction}

Hepatic steatosis is a major risk factor for liver resection and transplantation. Recently, the epidemic of obesity in developed countries has increased, along with its attendant complications, including metabolic syndrome and hepatic steatosis. Between 6 and 33\% of individuals in the general population [1] and $70-80 \%$ of obese patients have hepatic steatosis. Liver transplants using steatotic liver grafts are associated with a high primary graft nonfunction rate compared with nonsteatotic livers $[2,3]$. Along with transplantation, steatotic livers have a negative impact in other clinical situations, such as hepatectomy, shock, and cardiac arrest, which are all subject to warm hepatic ischemia-reperfusion injury (IRI) [4].

Although it is generally accepted that steatotic livers are particularly vulnerable to hepatic IRI, results from animal experiments indicate that the mechanisms underlying IRI are different in nonsteatotic and steatotic livers [5]. Cellular hypoxia persists in fatty hepatocytes during IRI because the hepatic sinusoidal space is obstructed due to fat droplet accumulation in the cytoplasm of hepatocytes. This causes a reduction in sinusoidal blood flow [6] and a decrease in ATP synthase and increase in reactive oxygen species (ROS) production within the steatotic liver is induced by the increased level of mitochondrial uncoupling protein-2, a mitochondrial inner membrane protein that mediates proton leakage across the inner membrane by uncoupling substrate oxidation from ATP synthesis [7-9]. However, the reason why hepatic IRI is increased in steatotic liver has not yet been fully elucidated.

Among a large number of pharmacological agents to protect against IRI in animal models, activated protein C (APC), an anticoagulant, has been shown to have cytoprotective 
effects against IRI in several organs [10, 11]. Previously, we reported that APC administration had a cytoprotective effect on hepatic IRI in rat models, by preventing recruitment of inflammatory cells, ameliorating sinusoidal endothelial cell injury, and maintaining sinusoidal blood flow [11]. Previous studies provide evidence supporting the idea of direct cytoprotective actions of APC in which endothelial protein $\mathrm{C}$ receptor- (EPCR-) bound APC activates protease-activated receptor 1 (PAR1) to initiate signaling on endothelial cells $[12$, 13]. In contrast, a recent study using a myocardial IRI model elucidated another mechanism of APC, namely, triggering adenosine monophosphate-activated protein kinase (AMPK) signaling: phosphorylation of AMPK mediates dramatic changes in cell metabolism, cell survival, and other functions [14]. In steatotic liver, mitochondria in hepatocytes produce excessive amounts of reactive oxidative species (ROS) leading to damage of mitochondrial inner membrane proteins and a consequent decrease of mitochondrial adenosine triphosphate (ATP) production [15]. Moreover, hepatic ATP stores are reduced in steatotic livers which are more vulnerable to necrosis after transient hepatic ischemia [16]. To the best of our knowledge, there have been no previous studies investigating whether APC treatment is beneficial against steatotic liver IRI, compared with nonsteatotic liver. On the basis of evidence from these previous studies, we speculate that APC might have a different mechanism in steatotic liver compared with nonsteatotic liver, namely, that APC attenuates I/R injury by preventing the depletion of ATP via AMPK activation, and this effect is specific to steatotic liver.

In the present study, we compared the cytoprotective effects of APC administration between nonsteatotic and steatotic liver IRI in a mouse model, in an attempt to elucidate the theoretical mechanism by which APC attenuates liver damage specifically in steatotic liver.

\section{Materials and Methods}

2.1. Animals. Five-week-old male mice (C57BL/6; Japan SLC, Inc.) were fed either a normal diet (ND mice) or a high fat diet (60\% calories from fat; Research Diets number D12492) (HF mice) for 9 weeks (Figure 1(a)). All experiments were conducted in compliance with the Guideline for Animal Experiments in Mie University Graduate School of Medicine.

2.2. Activated Protein C. Human plasma-derived APC was kindly provided by the Chemo-Sero-Therapeutic Research Institute (Kumamoto, Japan). ND and HF mice were randomly assigned to either APC treatment or control groups, resulting in the following four groups being established: (1) ND-APC, (2) ND-Control, (3) HF-APC, and (4) HF-Control. The number of animals used in each group was 12. APC $(0.2 \mathrm{mg} / \mathrm{kg}$ of body weight) or saline solution (the volume equivalent to APC solution) was intravenously administered just prior to surgery and at $8 \mathrm{~h}$ and $16 \mathrm{~h}$ after reperfusion $[11,14]$.

2.3. Model of Partial Lobar Liver IRI. A warm hepatic IRI model was established in 14-week-old male mice (i.e., after
9 weeks of diet feeding). Mice were anaesthetized with isoflurane and livers were exposed through a midline laparotomy. The arterial and portal venous blood supplies were interrupted to the cephalad lobes of the liver for 60 min using an atraumatic clip. The right hepatic lobe and the caudate lobe were perfused to prevent intestinal congestion. After $60 \mathrm{~min}$ of ischemia, the clip was removed, thus initiating hepatic reperfusion. Mice were sacrificed $4 \mathrm{~h}$ or $24 \mathrm{~h}$ after reperfusion $(n=6$ in each group; Figure 1(b)). Body weight was measured before the operation.

2.4. Serum Transaminases. Serum alanine transaminase (ALT) and serum aspartate transaminase (AST) levels were measured using a commercially available kit (Wako Pure Chemical Industries Ltd., Osaka, Japan), following manufacturer's instructions.

2.5. Histology and Immunohistochemistry. Liver histology and immunohistochemistry were performed as previously reported $[17,18]$. Liver specimens embedded in paraffin were processed for hematoxylin and eosin (H\&E) staining. The histological damage due to hepatic IRI was assessed using the modified Suzuki score [19], as well as by the extent of the necrotic area. In the modified Suzuki score, sinusoidal congestion, hepatocyte necrosis, and ballooning degeneration were graded from 0 to 4 . No necrosis, congestion, or centrilobular ballooning was given a score of 0 , whereas severe congestion and ballooning degeneration and $60 \%$ lobular necrosis were given a score of 4 . The degree of hepatic necrosis $24 \mathrm{~h}$ after IRI was assessed in H\&E-stained paraffin sections; H\&E stains were digitally photographed and the percent of necrosis was quantified using NIH Image J software in a manner blinded to the different experimental groups, as previously described [20]. Liver steatosis was evaluated using Oil Red O staining. Immunohistochemistry was performed using Ly6G (1A8) from BioLegend (San Diego, CA), MAC-1 (M1/70) and PECAM-1 (MEC13.3) from BD Biosciences (San Jose, CA), and phospho-AMPK ( $\mathrm{p}$ AMPK) (40H9) from Cell Signaling Technology (Beverly, MA), with all antibodies used at optimal dilutions. The results were evaluated by an average of 10 times' counting in 40 highpower $(\times 400$ magnification) fields per section.

2.6. Western Blot Analysis. Western blots were performed as described previously [17]. PVDF membranes were incubated with antibodies against PECAM-1 (epitope within extracellular domain; SC-28188; Santa Cruz Biotechnology, Santa Cruz, CA) and p-AMPK (40H9; Cell Signaling Technology). After development, membranes were stripped and reblotted with antibodies against AMPK (D5A2; Cell Signaling Technology) and actin (Cell Signaling Technology). Prestained molecular weight markers (Protein MultiColor III; BioDynamics Laboratory Inc., Tokyo, Japan) served as standards. Relative quantities of protein were determined using a densitometer (NIH Image J software).

2.7. Cell Culture. Primary steatotic hepatocytes were isolated from $\mathrm{HF}$ mice. To isolate primary murine hepatocytes, 


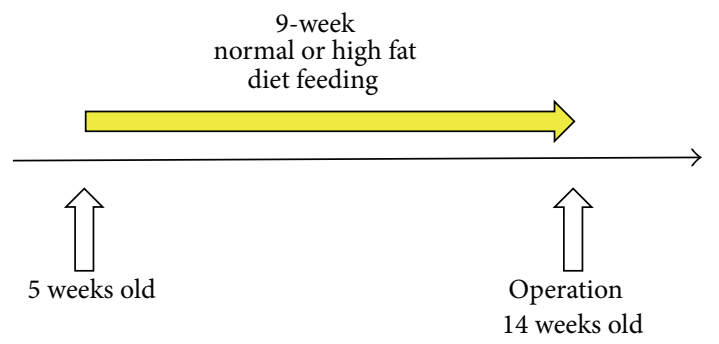

(a)

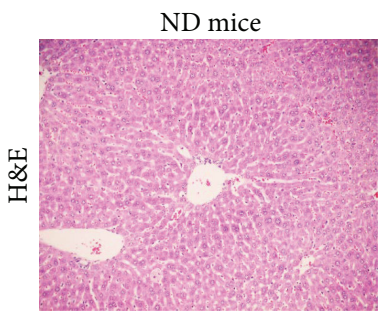

(A)

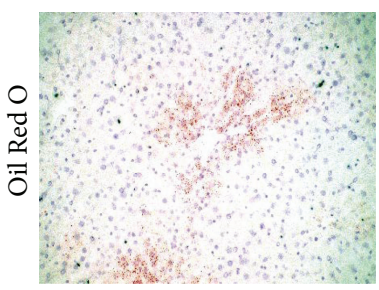

(C)

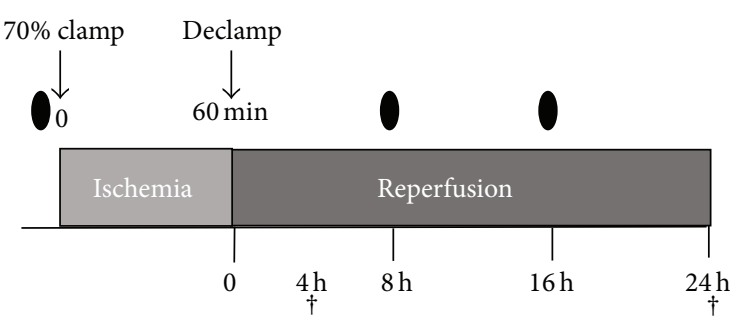

Administration of saline or APC

$\dagger$ Sacrifice

(b)

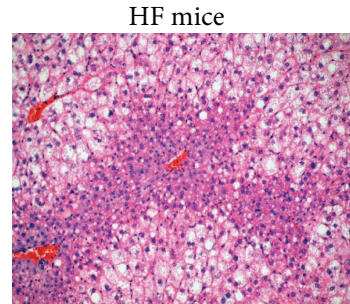

(B)

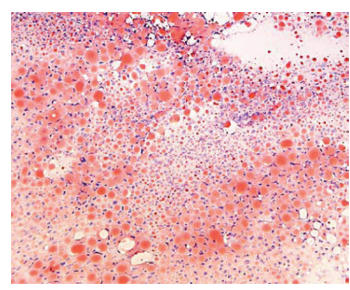

(D)

(c)

FIGURE 1: Development of steatotic mice and method of IRI. Five-week-old C57BL/6 male mice were fed either a normal diet (ND mice) or a high fat diet (HF mice) for 9 weeks (a). Blood supply to the cephalad lobes of the liver was interrupted for 60 min using an atraumatic clip. After $60 \mathrm{~min}$ of ischemia, the clip was removed. APC or saline solution was administered just prior to surgery and at $8 \mathrm{~h}$ and $16 \mathrm{~h}$ after reperfusion. Mice were sacrificed $4 \mathrm{~h}$ or $24 \mathrm{~h}$ after reperfusion (b). Representative H\&E ((c)-(A), (c)-(B)) and Oil Red O staining ((c)-(C), (c)-(D)) of liver tissue after 9 weeks on the experimental diets. There was no steatosis in ND mice ((c)-(A), (c)-(C)). After 9 weeks of HF diet feeding, macrosteatosis was observed using H\&E staining and Oil Red O staining ((c)-(B), (c)-(D)). The original magnification was $\times 100$.

anesthetized mice were subjected to a midline laparotomy and cannulation of the portal vein followed by liver perfusion with an EGTA-chelating perfusion buffer (EGTA: $190 \mathrm{mg}$, glucose: $900 \mathrm{mg}$, HEPES: $10 \mathrm{~mL}$ of $1 \mathrm{M}$ stock solution, KCL: $400 \mathrm{mg}, \mathrm{Na}_{2} \mathrm{HPO}_{4}-2 \mathrm{H}_{2} \mathrm{O}: 151 \mathrm{mg}, \mathrm{NaCl}: 8 \mathrm{~g}, \mathrm{NaH}_{2} \mathrm{PO}_{4}-\mathrm{H}_{2} \mathrm{O}$ : $7 \mathrm{mg}$, and $\mathrm{NaHCO}_{3}: 350 \mathrm{mg}$, made up to $1 \mathrm{~L}$ with $\mathrm{dH}_{2} \mathrm{O}$ ). After perfusion with $0.4 \%$ collagenase buffer $\left(\mathrm{CaCl}_{2}-2 \mathrm{H}_{2} \mathrm{O}\right.$ : $560 \mathrm{mg}$, HEPES: $10 \mathrm{~mL}$ of $1 \mathrm{M}$ stock solution, KCL: $400 \mathrm{mg}$, $\mathrm{Na}_{2} \mathrm{HPO}_{4}-2 \mathrm{H}_{2} \mathrm{O}: 151 \mathrm{mg}, \mathrm{NaCl}: 8 \mathrm{~g}, \mathrm{NaH}_{2} \mathrm{PO}_{4}-\mathrm{H}_{2} \mathrm{O}: 7 \mathrm{mg}$, $\mathrm{NaHCO}_{3}: 350 \mathrm{mg}$, and collagenase $\mathrm{P}: 400 \mathrm{mg}$, made up to $1 \mathrm{~L}$ with $\mathrm{dH}_{2} \mathrm{O}$ ), livers were minced and cells dispersed in culture medium; hepatocyte and nonparenchymal cells were separated using low-speed centrifugation methods. Isolated mouse steatotic hepatocytes $\left(2 \times 10^{5} /\right.$ well $)$ were cultured in DMEM with $10 \%$ FBS on 24-well collagen-coated plate at $37^{\circ} \mathrm{C}$ with $5 \% \mathrm{CO}_{2}$ for $12 \mathrm{~h}$. Hepatocytes were incubated in the presence or absence of $\mathrm{H}_{2} \mathrm{O}_{2}(500 \mathrm{nM})$ and/or APC $(300 \mathrm{nM})$ and/or compound C $(10 \mu \mathrm{M})$ (Tocris Bioscience, Bristol, UK), which is an inhibitor of AMPK. After $24 \mathrm{~h}$ culture, the cell lysates were prepared for protein evaluation, and the supernatants were collected for cytotoxicity assays. Cell viability was assessed by counting an aliquot in the presence of $0.4 \%$ Trypan blue. Cell cytotoxicity was assessed by AST levels in culture media. ATP levels of hepatocytes were measured using a commercially available kit (BioVision, Palo Alto, CA), according to the manufacturer's instructions.

2.8. Data Analysis. The results of continuous variables are expressed as the mean value \pm standard deviation. Statistical comparisons between groups of normally distributed data were performed using the Mann-Whitney $U$ test with SPSS software (SPSS Inc., Chicago, IL). $P$ values less than 0.05 were considered statistically significant.

\section{Results}

3.1. HF Mice Develop Macrosteatosis. There was no observation of steatosis in ND mice (Figures $1(\mathrm{c})-(\mathrm{A})$ and $1(\mathrm{c})$ (C)). HF mice developed fatty livers which resembled those 

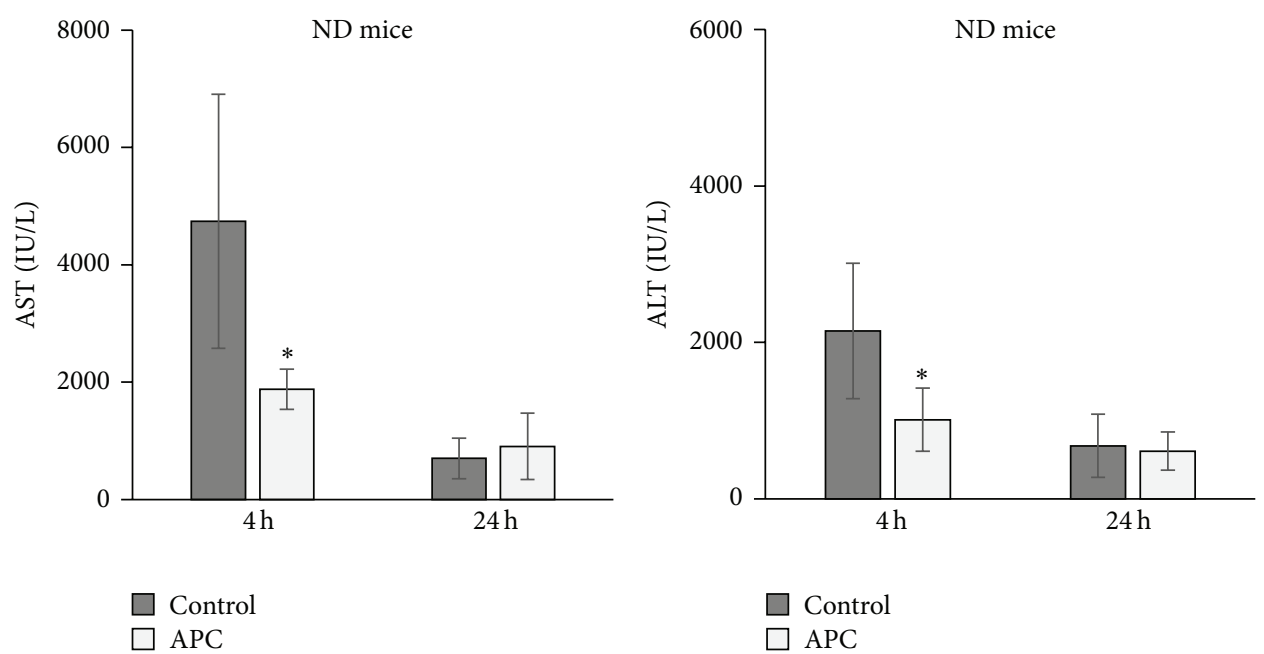

(A)

(B)

(a)
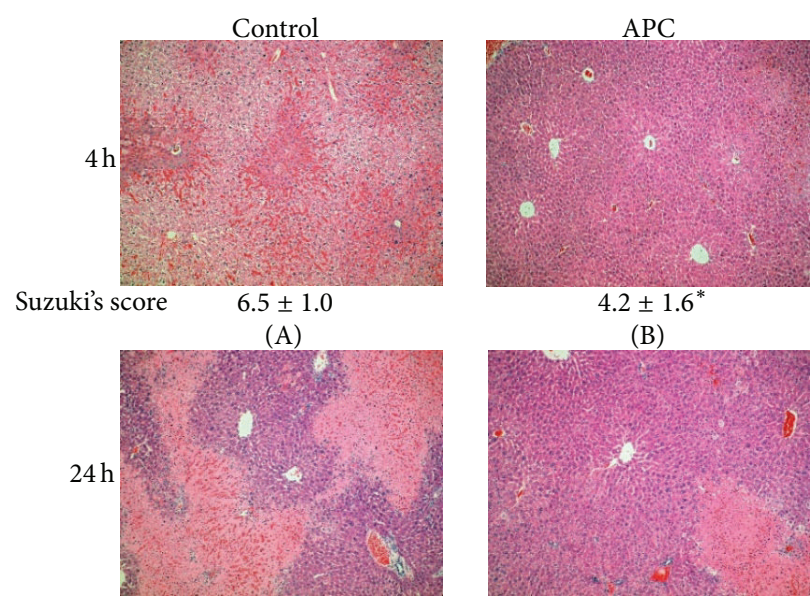

$4.2 \pm 1.6$

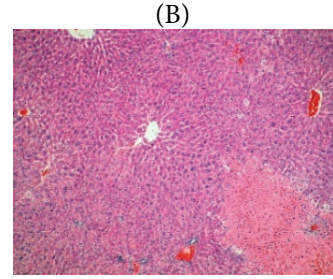

Suzuki's score $\quad 8.5 \pm 1.2$

$7.5 \pm 0.5$

Necrosis area (\%) $56.7 \pm 28.5$

(C)

ND mice

$22.9 \pm 13.8$

(b)
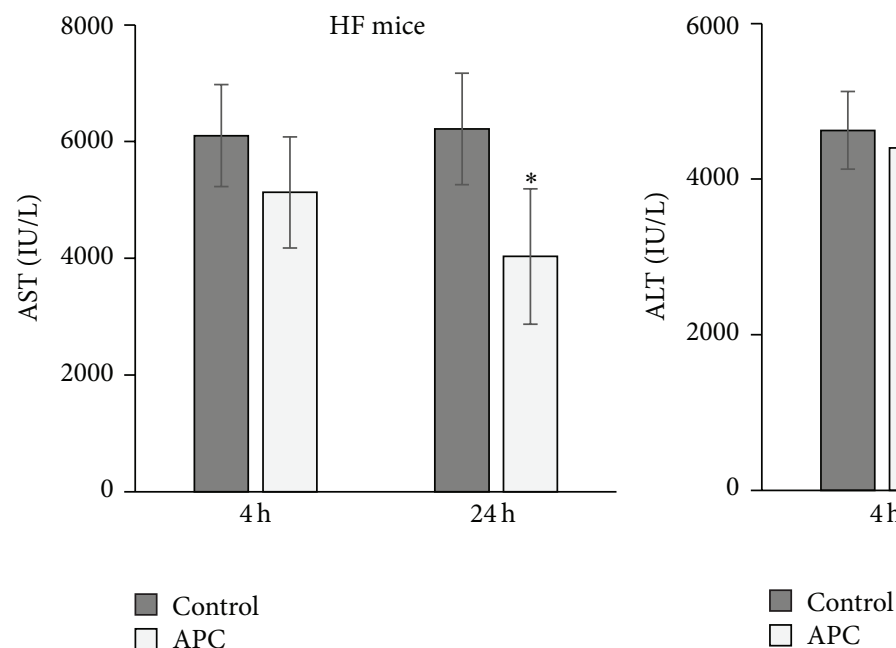

(A)

(c)

FIgURE 2: Continued. 


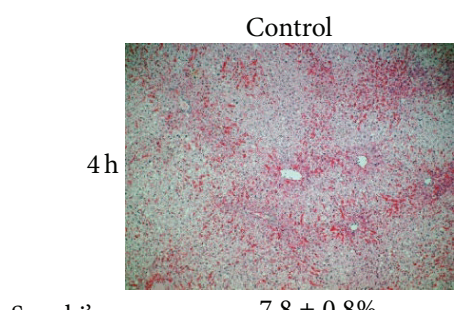

$\begin{array}{ll}\text { Suzuki's score } & 7.8 \pm 0.8 \% \\ \text { (A) }\end{array}$

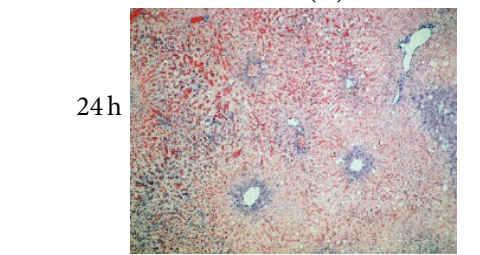

Suzuki's score $\quad 11.1 \pm 0.7$

Necrosis area (\%) $\quad 84.2 \pm 6.8$

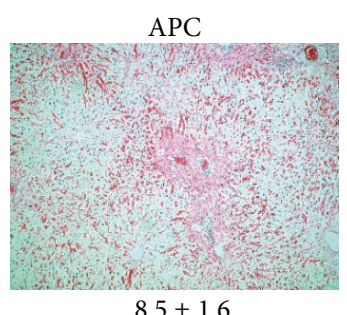

(B)

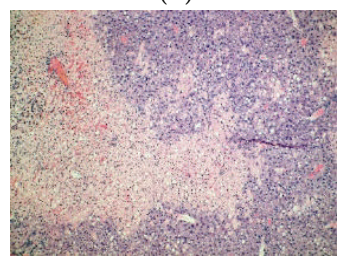

$10.4 \pm 0.5$

$66.7 \pm 10.5^{*}$

(D)

(C) HF mice

(d)

FIGURE 2: Transaminase levels and histology in ND and HF mice. Serum AST and ALT levels at $4 \mathrm{~h}$ were significantly decreased in ND-APC compared with ND-Control mice $\left({ }^{*} P<0.05\right)$. There was no significant difference at $24 \mathrm{~h}$ between ND-APC and ND-Control mice $((\mathrm{a})$ (A), (a)-(B)). H\&E staining showed that the ND-APC had significantly preserved lobular architecture and reduced intrasinusoidal/vascular congestion compared with ND-Control at $4 \mathrm{~h}((\mathrm{~b})-(\mathrm{A}),(\mathrm{b})-(\mathrm{B}))$. The necrotic area within livers was significantly reduced in ND-APC compared with ND-Control mice at $24 \mathrm{~h}\left({ }^{*} \mathrm{P}<0.05\right)((\mathrm{b})-(\mathrm{C}),(\mathrm{b})-(\mathrm{D}))$. While serum AST and ALT levels at $24 \mathrm{~h}$ were significantly decreased in HF-APC compared with HF-Control mice $\left({ }^{*} \mathrm{P}<0.05\right)$, there was no significant difference at $4 \mathrm{~h}$ between HF-APC and HF-Control mice ((c)-(A), (c)-(B)). In HF mice, however, liver tissues in both the HF-APC and HF-Control groups showed marked changes in vacuolization and intrasinusoidal/vascular congestion ((d)-(A), (d)-(B)). Although there was more severe necrosis in HF mice than in ND mice, the necrotic area of hepatocytes was significantly reduced in HF-APC compared with HF-Control mice at $24 \mathrm{~h}\left({ }^{*} \mathrm{P}<0.05\right)((\mathrm{d})-(\mathrm{C})$, (d)-(D)). The numbers under the pictures show the modified Suzuki score and the percentage of necrotic area (\%). The original magnification was $\times 100(b, d)$.

of human obesity [21]. In our experimental setting, HF mice were characterized by $50 \%$ liver steatosis, with macrovesicular fatty infiltration, as assessed by H\&E (Figure 1(c)-(B)) and Oil Red O staining (Figure 1(c)-(D)). Moreover, the body weight of 9-week HF mice was significantly higher than that of ND mice $(41.3 \pm 2.1$ versus $27.7 \pm 1.5 \mathrm{~g}, P<0.05)$.

\subsection{APC Ameliorates Hepatocellular Injury in ND and HF} Mice at Different Time Points. In ND mice, APC treatment significantly reduced serum AST and ALT levels at $4 \mathrm{~h}$ (AST: $1,879 \pm 344$ versus $4,741 \pm 2,167 \mathrm{IU} / \mathrm{L} ; \mathrm{ALT}: 1,012 \pm 403$ versus $2,146 \pm 866 \mathrm{IU} / \mathrm{L}, P<0.05)$. However, there were no significant differences at $24 \mathrm{~h}$ between ND-APC and NDControl mice (AST: $903 \pm 565$ versus $700 \pm 344 \mathrm{IU} / \mathrm{L}$; ALT: $610 \pm 243$ versus $678 \pm 403$ IU/L) (Figures 2(a)-(A) and 2(a)(B)). In the assessment of histological damage, necrotic area could not be accurately assessed at $4 \mathrm{~h}$ because development of necrosis was scarce. The modified Suzuki score at $4 \mathrm{~h}$ was significantly lower in ND-APC than in ND-Control mice: $4.2 \pm 1.6$ versus $6.5 \pm 1.0, P<0.05$ (Figures $2(\mathrm{~b})-(\mathrm{A})$ and $2(\mathrm{~b})$ (B)), while at $24 \mathrm{~h}$ there was no significant difference between the two groups: $7.5 \pm 0.5$ versus $8.5 \pm 1.2$ (Figures $2(\mathrm{~b})-(\mathrm{C})$ and 2(b)-(D)). The necrotic area at $24 \mathrm{~h}$ was significantly lower in ND-APC than in ND-Control mice: $22.9 \pm 13.8$ versus $56.7 \pm 28.5 \%, P<0.05$ (Figures $2(\mathrm{~b})-(\mathrm{C})$ and $2(\mathrm{~b})-(\mathrm{D})$ ).

In HF mice, APC treatment did not significantly reduce serum AST or ALT levels at $4 \mathrm{~h}$ compared with HF-Control mice (AST: 5,130 \pm 954 versus 6,103 $\pm 873 \mathrm{IU} / \mathrm{L}$; ALT: 4,403 \pm 715 versus $4,627 \pm 499 \mathrm{IU} / \mathrm{L})$, while it significantly improved steatotic liver function at $24 \mathrm{~h}$ (AST: 4,032 $\pm 1,160$ versus 6,218 $\pm 954 \mathrm{IU} / \mathrm{L} ;$ ALT: $1,876 \pm 523$ versus 3,037 $\pm 715 \mathrm{IU} / \mathrm{L}$, $P<0.05$ ) (Figures 2(c)-(A) and 2(c)-(B)). In the assessment of histological damage, the modified Suzuki score was very difficult to assess in steatotic liver due to the large number of fatty droplets, and necrotic area could not be evaluated at $4 \mathrm{~h}$ because development of necrosis was scarce. The modified Suzuki scores at $4 \mathrm{~h}$ and $24 \mathrm{~h}$ were not significantly different between HF-APC and HF-Control mice: $8.5 \pm 1.6$ versus $7.8 \pm$ 0.8 at $4 \mathrm{~h}$ (Figures 2(d)-(A) and 2(d)-(B)); $10.4 \pm 0.5$ versus $11.1 \pm 0.7$ at $24 \mathrm{~h}$ (Figures 2(d)-(C) and 2(d)-(D)). In contrast, the necrotic area at $24 \mathrm{~h}$ was significantly lower in HF-APC than in HF-Control mice: $66.7 \pm 10.5$ versus $84.2 \pm 6.8 \%$ $(P<0.05)$ (Figures $2(\mathrm{~d})-(\mathrm{C})$ and $2(\mathrm{~d})-(\mathrm{D}))$.

\subsection{APC Prevents Intrahepatic Leucocyte Infiltration in ND} and HF Mice. To determine whether APC affects local leucocyte infiltration, we assessed Ly6G-positive cells and MAC1-positive cells using immunohistochemical staining. The number of Ly6G-positive cells in the liver was significantly decreased in ND-APC mice compared with ND-Control mice at $4 \mathrm{~h}(20.9 \pm 4.6$ versus $35.7 \pm 1.9, P<0.05)$ (Figures 3(a)-(A), 3(a)-(B), and 3(b)). However, at $24 \mathrm{~h}$, there were no significant differences in the number of Ly6G-positive cells that had infiltrated when comparing the two groups 


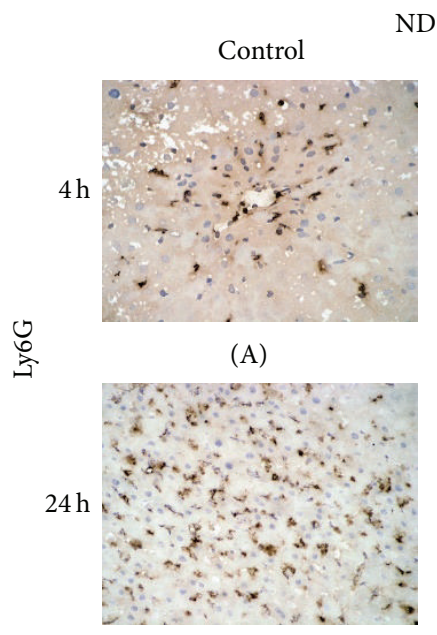

(C)

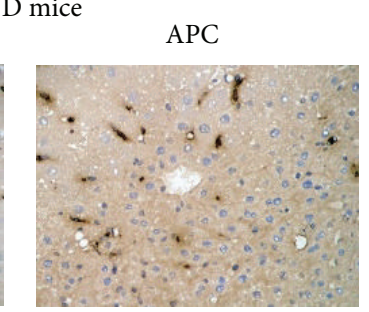

(B)

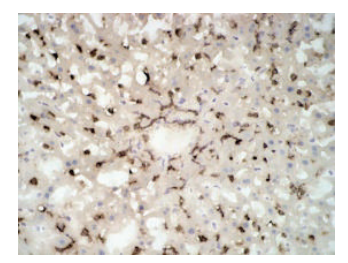

(D)

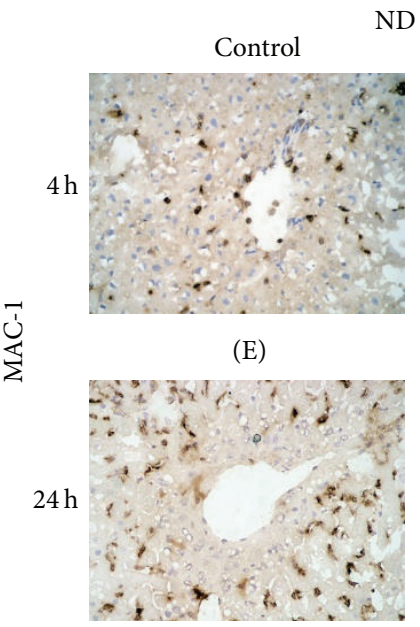

(G)

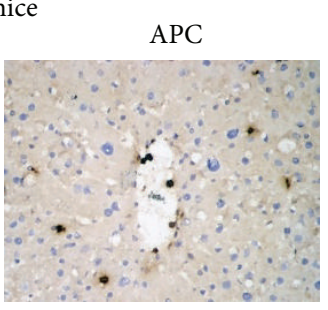

(F)

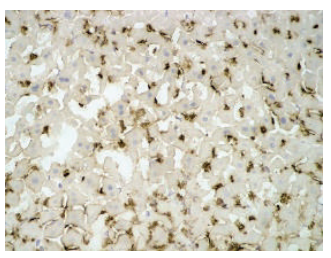

(H)

(a)

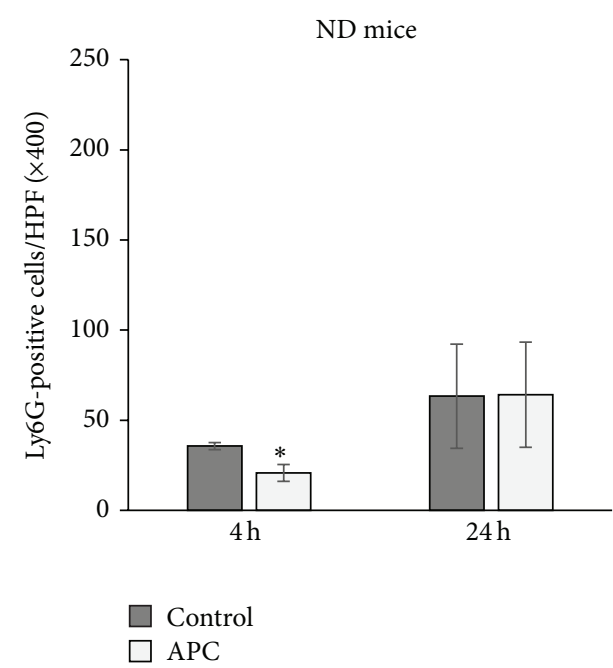

(b)

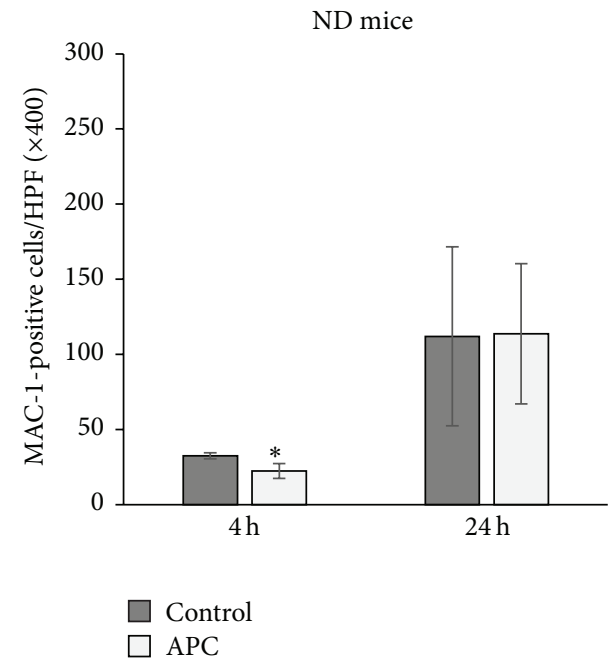

(c)

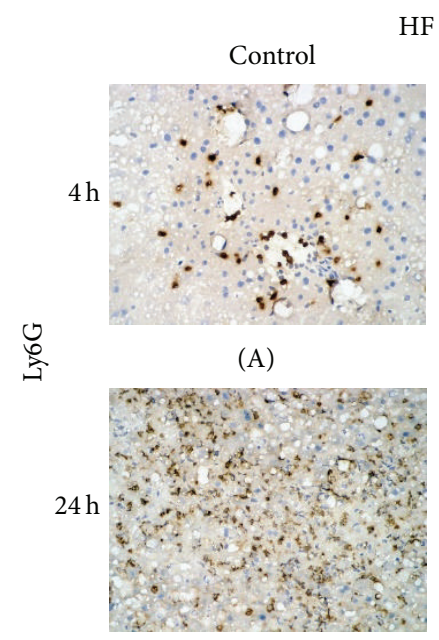

(C)

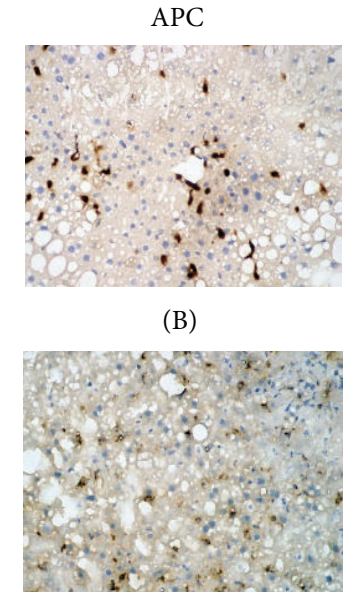

(D)

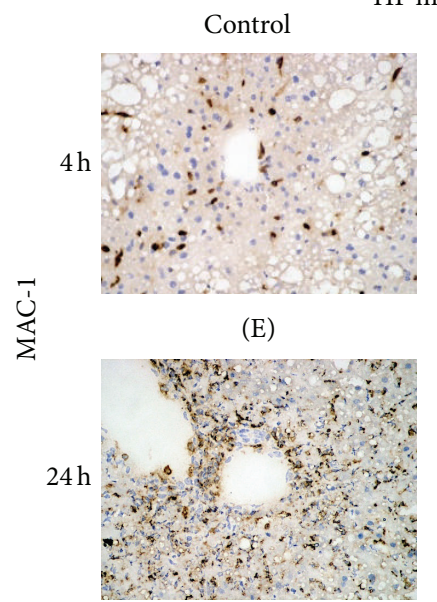

(G)

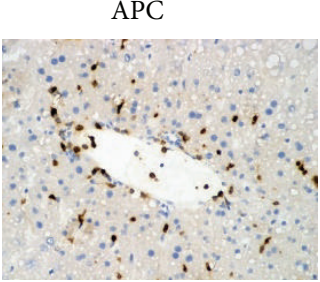

(F)

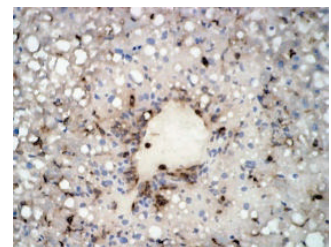

(H)

(d)

Figure 3: Continued. 


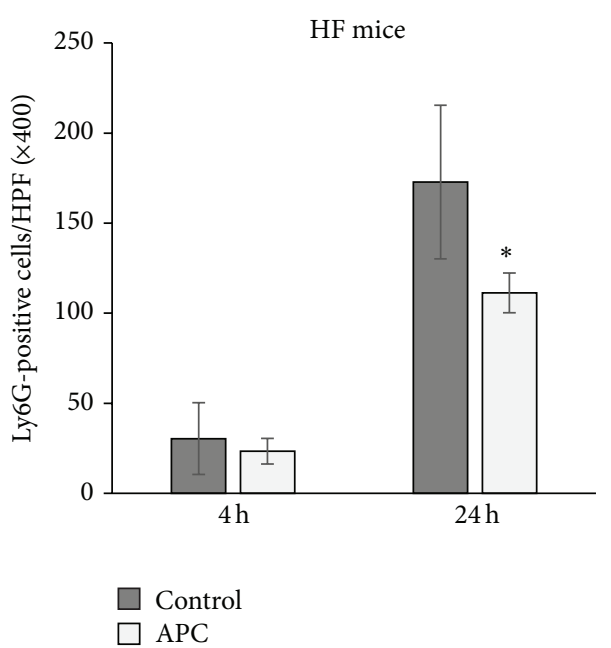

(e)

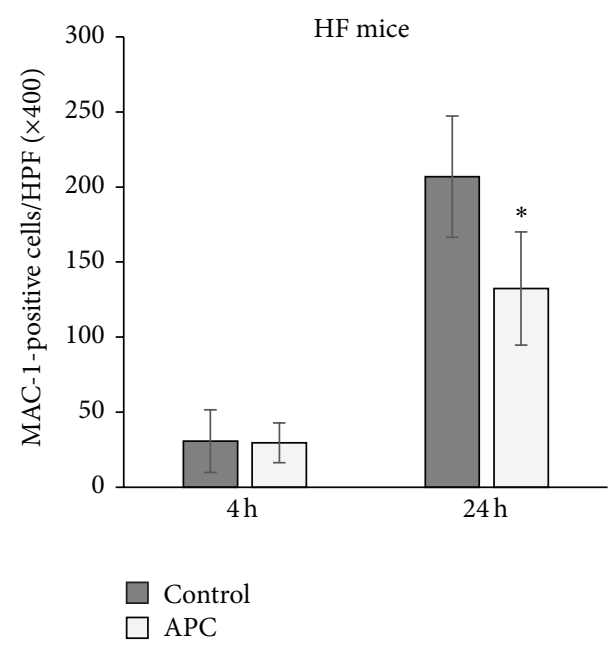

(f)

FIGURE 3: Leukocyte infiltration $4 \mathrm{~h}$ and $24 \mathrm{~h}$ after reperfusion. Infiltration of Ly6G-positive cells ((a)-(A), (a)-(B), and (b)) and MAC-1positive cells ((a)-(E), (a)-(F), and (c)) in the liver was significantly decreased in ND-APC compared with ND-Control mice at $4 \mathrm{~h}\left({ }^{*} P<0.05\right)$. However, in HF mice, infiltration of Ly6G-positive cells ((d)-(C), (d)-(D), and (e)) and MAC-1-positive cells ((d)-(G), (d)-(H), and (f)) was significantly decreased in HF-APC livers compared with HF-Control livers at $24 \mathrm{~h}\left({ }^{*} \mathrm{P}<0.05\right)$. There was no significant difference at $4 \mathrm{~h}$ between HF-APC and HF-Control mice. The original magnification was $\times 400$ (a, d).

$(64.1 \pm 29.2$ versus $63.4 \pm 28.8)$ (Figures 3(a)-(C), 3(a)-(D), and 3(b)). The number of MAC-1-positive cells in the liver was significantly decreased in ND-APC compared with NDControl mice at $4 \mathrm{~h}(22.3 \pm 4.9$ versus $32.5 \pm 1.9, P<0.05)$ (Figures 3(a)-(E), 3(a)-(F), and 3(c)). However, at $24 \mathrm{~h}$, there were no significant differences in the number of MAC-1positive cells between the two groups $(113.8 \pm 46.7$ versus $111.9 \pm 59.6$ ) (Figures 3(a)-(G), 3(a)-(H), and 3(c)).

In HF mice, there were no significant differences in the number of Ly6G-positive cells at $4 \mathrm{~h}$ between the two groups (23.4 \pm 7.1 versus 30.4 \pm 19.9 ) (Figures 3(d)-(A), 3(d)-(B), and $3(\mathrm{e})$ ), while at $24 \mathrm{~h}$ the number was significantly decreased in HF-APC mice compared with HF-Control mice (111.4 \pm 11.0 versus $172.8 \pm 42.6, P<0.05$ ) (Figures 3(d)-(C), 3(d)-(D), and $3(\mathrm{e}))$. Although there were no significant differences in the number of MAC-1-positive cells at $4 \mathrm{~h}$ between the two groups $(29.5 \pm 13.2$ versus $30.7 \pm 20.8)$ (Figures $3(\mathrm{~d})$-(E), $3(\mathrm{~d})-(\mathrm{F})$, and $3(\mathrm{f}))$, their number was significantly decreased in HF-APC mice compared with HF-Control mice at $24 \mathrm{~h}$ $(132.4 \pm 37.7$ versus $206.8 \pm 40.4, P<0.05)$ (Figures $3(\mathrm{~d})$ (G), 3(d)-(H), and 3(f)).

3.4. APC Prevents Sinusoidal Endothelial Cell Damage in ND Liver, but Not in HF Liver. PECAM-1 expression is readily detected on the intact vascular endothelium of naïve livers without IRI [18]. However, while PECAM-1 expression was relatively preserved on the vascular endothelium of ND-APC livers after IRI, it was largely absent from the vasculature of control livers, particularly at $4 \mathrm{~h}$ and $24 \mathrm{~h}$ (Figures 4 (a)(A)-4(a)-(D)). Indeed, the full length PECAM-1 (132 kDa) was detected in ND-APC livers and markedly depressed in ND-Control livers at $4 \mathrm{~h}$ and $24 \mathrm{~h}(4 \mathrm{~h}: 0.77 \pm 0.06$ versus $0.51 \pm 0.28 ; 24 \mathrm{~h}: 1.45 \pm 0.50$ versus $0.96 \pm 0.18, P<0.05)$
(Figures 4(b)-(A) and 4(b)-(B)). In contrast, sinusoidal endothelial structures were severely disrupted regardless of the APC administration at $4 \mathrm{~h}$ and $24 \mathrm{~h}$ in HF mice (Figures $4(\mathrm{c})-(\mathrm{A})-4(\mathrm{c})-(\mathrm{D}))$. There were no significant differences in relative quantities of PECAM-1 between HF-APC and HFControl livers ( $4 \mathrm{~h}: 1.02 \pm 0.26$ versus $0.84 \pm 0.13 ; 24 \mathrm{~h}$ : $0.57 \pm 0.19$ versus $0.50 \pm 0.14$ ) (Figures $4(\mathrm{~d})-(\mathrm{A})$ and $4(\mathrm{~d})$ (B)). Taken together, these data suggest that APC reduced sinusoidal damage due to hepatic IRI in ND livers, which is cytoprotective effect of APC, but this effect was abolished in steatotic livers, meaning that the other effects of APC needed to be considered, except in the case of endothelial cells.

3.5. APC Administration Activates AMPK Phosphorylation at $4 \mathrm{~h}$ in HF Livers, but Not in ND Livers. According to previous reports, APC is thought to potentiate the phosphorylation of AMPK, a serine-threonine kinase which maintains cellular energy stores and prevents energy depletion [14, 22, 23]. When we focused on the phosphorylation of AMPK in ND mouse livers, there were no significant differences at $4 \mathrm{~h}$ or $24 \mathrm{~h}$ between ND-APC and ND-Control mice ( $4 \mathrm{~h}: 0.58 \pm$ 0.11 versus $0.67 \pm 0.10 ; 24$ h: $1.45 \pm 0.47$ versus $1.09 \pm 0.34$ ) (Figures 5(a) and 5(b)). In contrast, AMPK phosphorylation was significantly increased in HF-APC mice compared with HF-Control mice at $4 \mathrm{~h}(1.21 \pm 0.21$ versus $0.83 \pm 0.13$, $P<0.05$ ) (Figure 5(c)). However, at $24 \mathrm{~h}$, there were no significant differences between the two groups in relative quantities of AMPK phosphorylation $(0.82 \pm 0.33$ versus $0.62 \pm$ 0.22 ) (Figure $5(\mathrm{~d})$ ). We then focused on the localization of p-AMPK in HF livers. Immunohistochemical staining of the liver revealed that $\mathrm{p}-\mathrm{AMPK}$ was predominantly expressed by the steatotic hepatocytes in the periportal area (zone I) $4 \mathrm{~h}$ after reperfusion (Figure 6). 


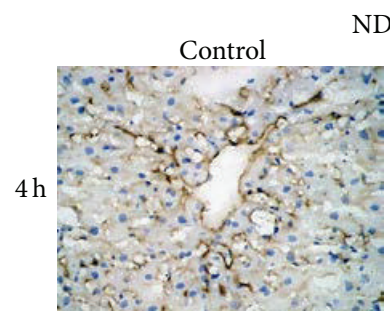

(A)

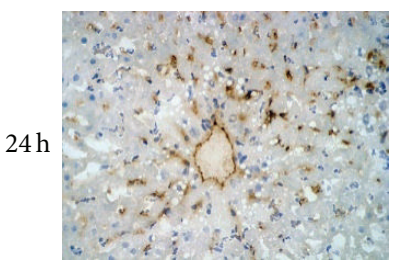

(C)

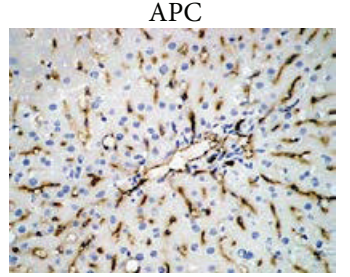

(B)

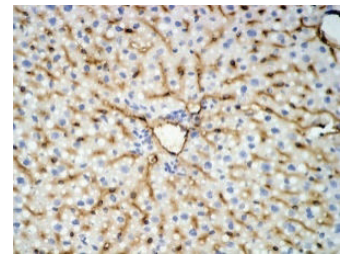

(D) (a)

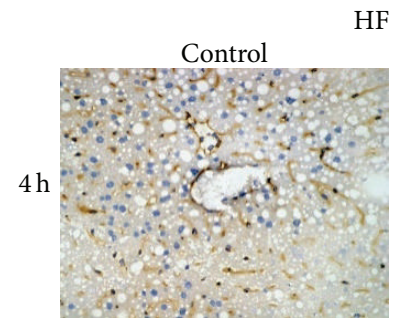

(A)

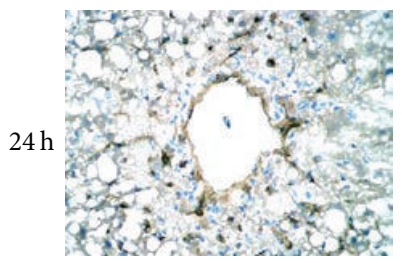

(C)

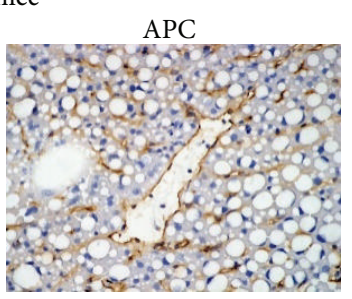

(B)

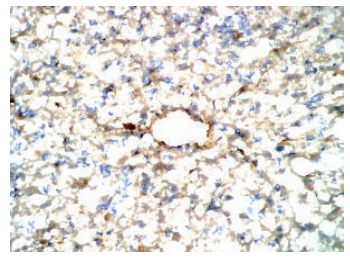

(D) c)

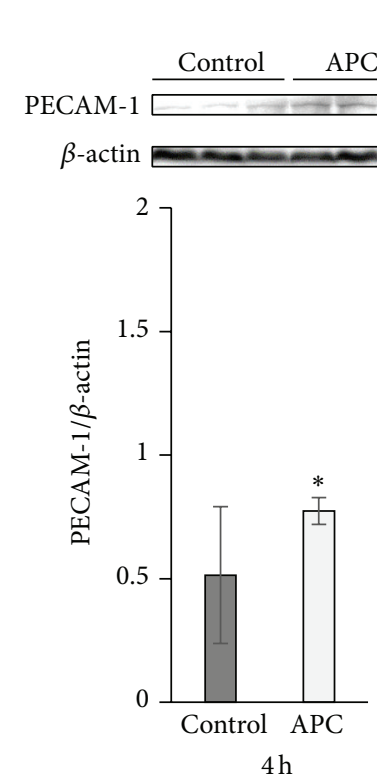

(A)

ND mice
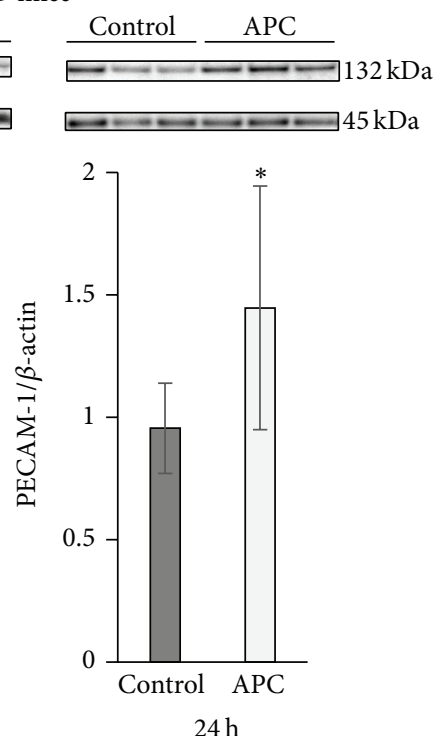

(B)

(b)

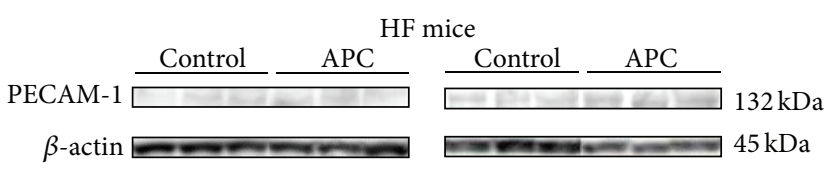

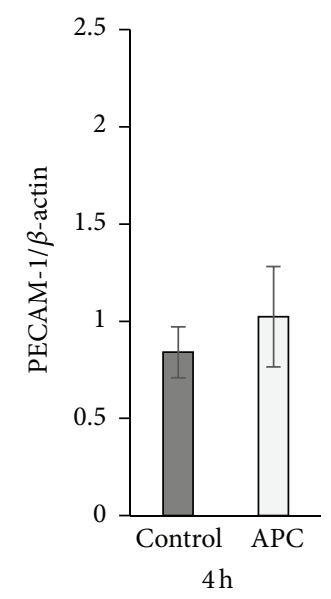

(A)

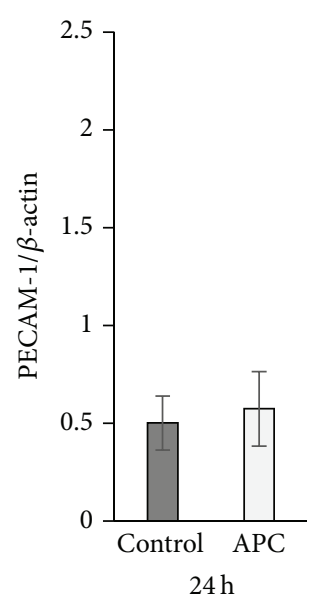

(B)

(d)

FIGURE 4: Sinusoidal endothelial cell damage in ND and HF mice. IRI disrupted sinusoidal vasculature regardless of APC administration in HF mice. In the liver tissue of ND mice, there was significant large number of sinusoidal endothelial cells, which were stained with PECAM-1 antibody in ND-APC than in ND-Control mice at $4 \mathrm{~h}((\mathrm{a})-(\mathrm{A}),(\mathrm{a})-(\mathrm{B})$, and (b)-(A)) and $24 \mathrm{~h}((\mathrm{a})-(\mathrm{C})$, (a)-(D), and (b)-(B)). In liver tissue of HF mice, sinusoidal endothelial cells which were stained with PECAM-1 antibody were disrupted regardless of APC administration at both $4 \mathrm{~h}((\mathrm{c})-(\mathrm{A}),(\mathrm{c})-(\mathrm{B})$, and $(\mathrm{d})-(\mathrm{A}))$ and $24 \mathrm{~h}((\mathrm{c})-(\mathrm{C}),(\mathrm{c})-(\mathrm{D})$, and $(\mathrm{d})-(\mathrm{B}))$.

3.6. APC Improves Hepatocyte Survival via Upregulation of $A M P K$ Phosphorylation In Vitro. According to the data from the in vivo AMPK analysis and evidence that p-AMPK was mainly detected in surviving hepatocytes at $4 \mathrm{~h}$ after IRI, we isolated primary steatotic hepatocytes, which are considered the main site of energy storage in steatotic liver, and evaluated the levels of AMPK phosphorylation and the degree of energy depletion in the presence or absence of APC administration.
The survival rates of steatotic hepatocytes were $75.4 \pm 1.0 \%$ in the sham group and $69.5 \pm 5.6 \%$ in response to APC alone, while they were only $56.6 \pm 10.1 \%$ in response to $\mathrm{H}_{2} \mathrm{O}_{2}$ alone. In response to $\mathrm{H}_{2} \mathrm{O}_{2}+\mathrm{APC}$, they were significantly increased (to $73.3 \pm 5.4 \%$ ) compared with $\mathrm{H}_{2} \mathrm{O}_{2}$ treatment alone. By adding an inhibitor of AMPK (compound $\mathrm{C}$ ), the survival rate was significantly decreased to $63.0 \pm 2.3 \%$ (Figure 7(a)). AST levels in the culture medium, an index of 


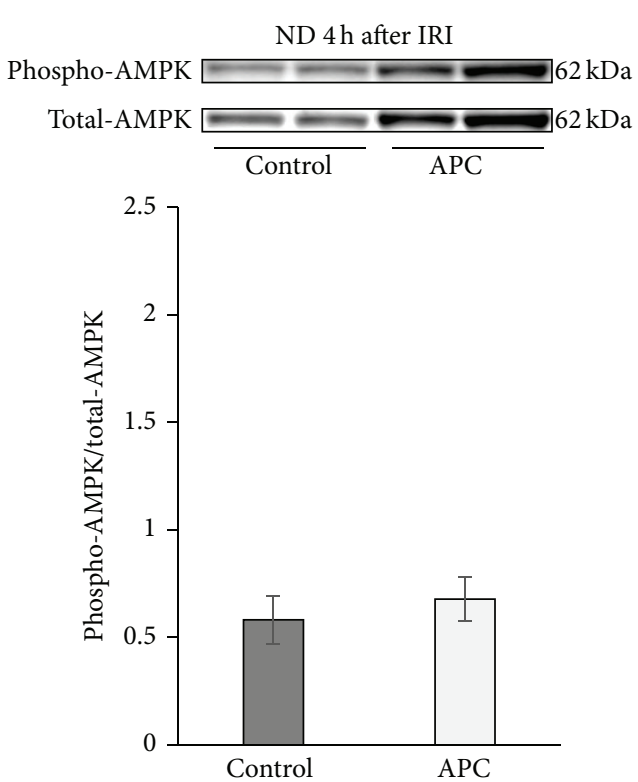

(a)
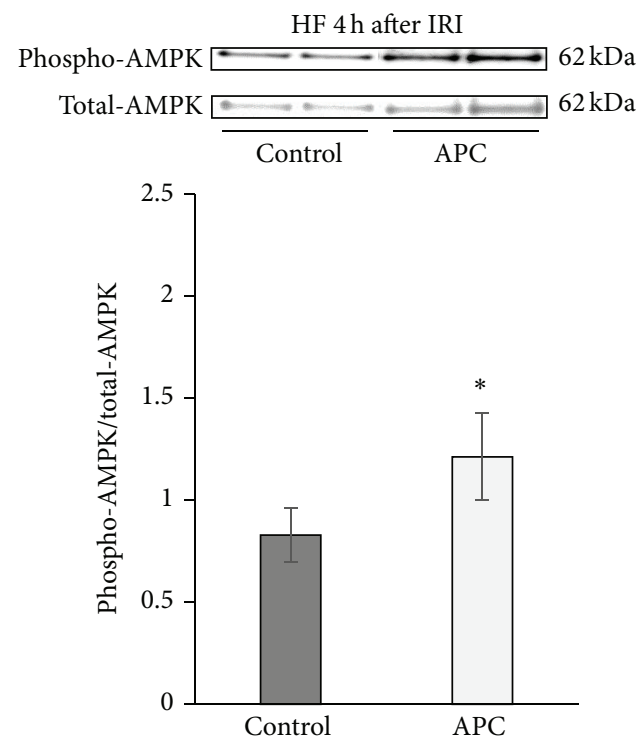

(c)

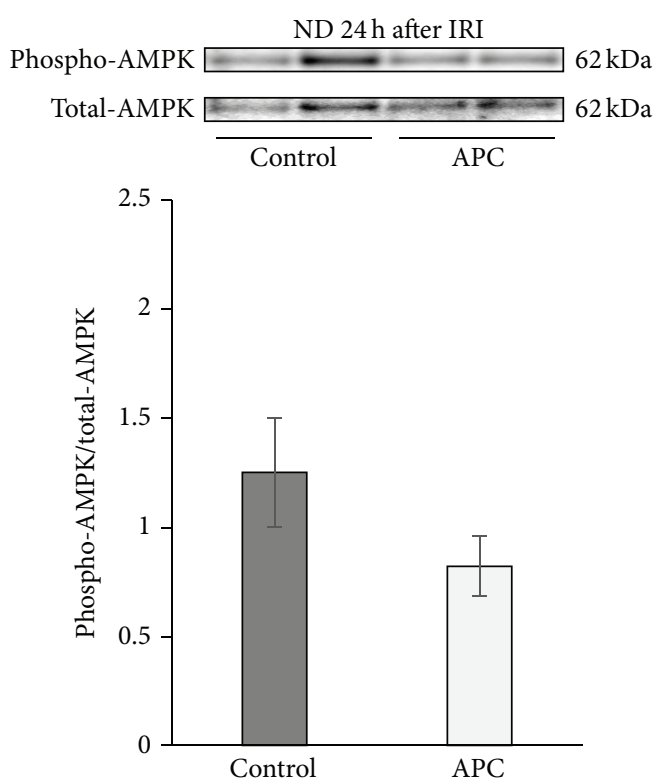

(b)
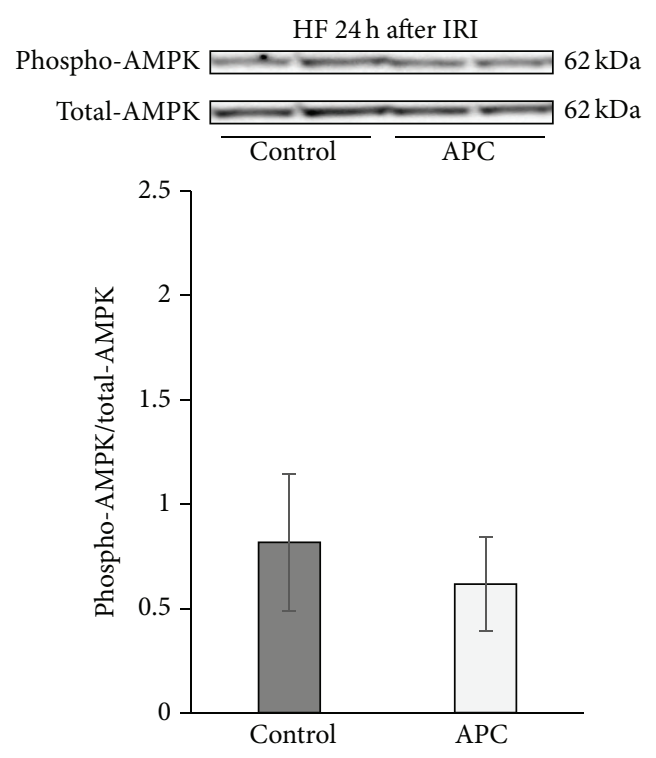

(d)

FIGURE 5: Phosphorylation of AMPK in steatotic liver tissue. In ND mice, there was no significant difference in phosphorylation of AMPK regardless of the APC administration at 4 or $24 \mathrm{~h}(\mathrm{a}, \mathrm{b})$. APC significantly increased phosphorylation of AMPK at $4 \mathrm{~h}$ in $\mathrm{HF}$ mice $\left({ }^{*} P<0.05\right)$ (c). At $24 \mathrm{~h}$, however, there was no significant difference in phosphorylation of AMPK between HF-APC and HF-Control mice (d).

cell cytotoxicity, were $41.5 \pm 0.7 \mathrm{IU} / \mathrm{L}$ in the sham group and $45.7 \pm 6.8 \mathrm{IU} / \mathrm{L}$ in response to APC alone, while they were increased to $87.5 \pm 15.7 \mathrm{IU} / \mathrm{L}$ in response to $\mathrm{H}_{2} \mathrm{O}_{2}$ alone. In the $\mathrm{H}_{2} \mathrm{O}_{2}+$ APC treatment, they were significantly decreased (to $53.1 \pm 19.7 \mathrm{IU} / \mathrm{L}$ ) compared with $\mathrm{H}_{2} \mathrm{O}_{2}$ treatment alone. By adding compound $\mathrm{C}$, the AST levels were significantly increased (to $73.9 \pm 17.9 \mathrm{IU} / \mathrm{L}$; Figure $7(\mathrm{~b})$ ). ATP levels of steatotic hepatocytes, after $24 \mathrm{~h}$ incubation with $\mathrm{H}_{2} \mathrm{O}_{2}$, were significantly preserved in the presence of APC, compared with the respective controls $(6.64 \pm 1.96$ versus $4.51 \pm$ $1.32 \mathrm{pmol} / \mu \mathrm{g}$ protein, $P<0.05$; Figure $7(\mathrm{c}))$. The relative quantities of AMPK phosphorylation in steatotic hepatocytes (as assessed by western blot analysis) were significantly higher in the presence of APC compared with controls $(2.08 \pm 0.75$ versus $1.07 \pm 0.26, P<0.01$; Figure $7(\mathrm{~d}))$.

\section{Discussion}

In the present study, both nonsteatotic and steatotic mice treated with APC showed significant improvements with respect to serum transaminase levels, liver histological damage, and leukocyte recruitment, and these effects were mainly 


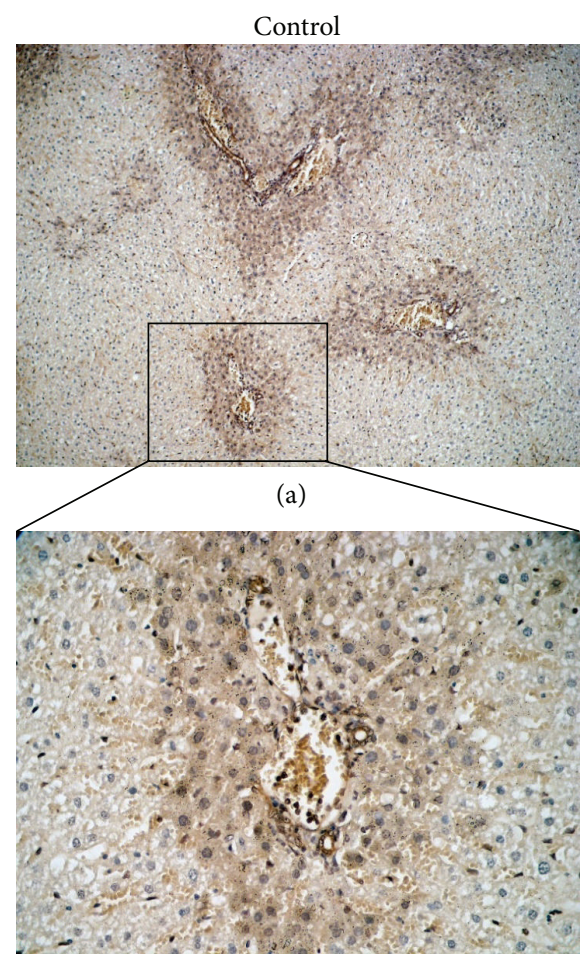

(c)

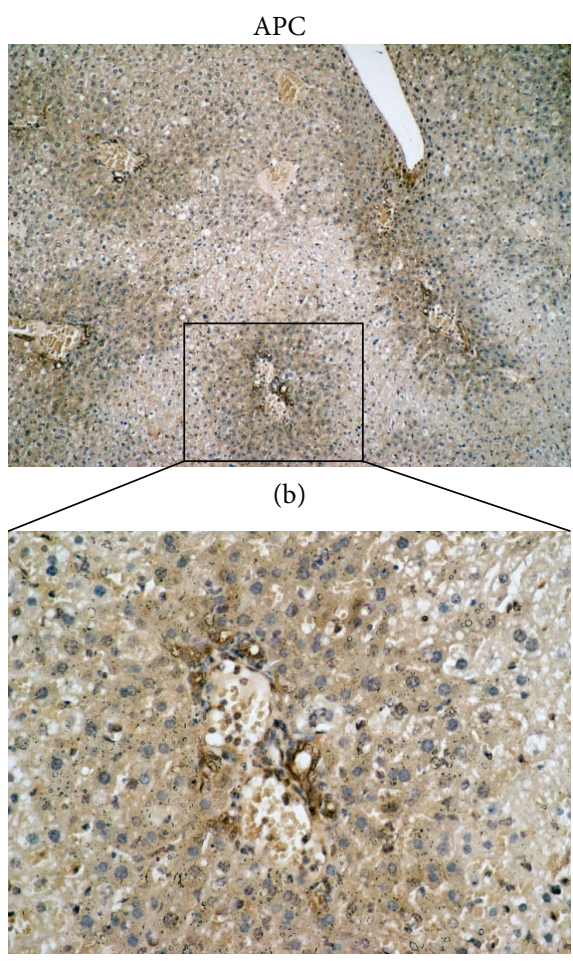

(d)

FIGURE 6: Immunohistochemical staining of phospho-AMPK in steatotic liver. Phospho-AMPK was predominantly expressed by the surviving steatotic hepatocytes particularly around the portal triad. The original magnification was $\times 100(a, c)$ or $\times 400(b, d)$.

observed at $4 \mathrm{~h}$ in nonsteatotic livers and at $24 \mathrm{~h}$ in steatotic livers. In nonsteatotic liver, the transaminase levels which were markedly increased at $4 \mathrm{~h}$ could be attenuated by APC treatment, while these levels were significantly decreased at $24 \mathrm{~h}$ in both groups, showing no significant difference. The modified Suzuki score of liver damage, which was derived from a combination of congestion, centrilobular ballooning, and necrosis, was significantly reduced by APC treatment at $4 \mathrm{~h}$, but not at $24 \mathrm{~h}$. The level of inflammatory cell infiltration assessed by immunochemical staining of Ly6G and MAC-1 was significantly attenuated at $4 \mathrm{~h}$ by APC treatment, while at $24 \mathrm{~h}$ it was significantly increased, showing no significant difference between the two groups. In contrast, necrotic area was significantly attenuated at $24 \mathrm{~h}$ by APC treatment. Taken together, these results suggest that APC treatment for IRI in nonsteatotic (normal) liver attenuated initial liver damage by inhibiting inflammatory cell infiltration, which in turn significantly reduces necrosis at $24 \mathrm{~h}$.

In contrast, in steatotic liver, APC treatment did not attenuate transaminase levels at $4 \mathrm{~h}$, which were markedly increased and significantly higher than those in nonsteatotic liver, although it did attenuate the levels at $24 \mathrm{~h}$. Histological assessment showed that APC treatment reduced necrotic area at $24 \mathrm{~h}$, although it did not affect the modified Suzuki score at $4 \mathrm{~h}$ or $24 \mathrm{~h}$. The number of inflammatory cells infiltrating, which was not significantly reduced at 4 h by APC treatment, was significantly increased at $24 \mathrm{~h}$ in both groups but this effect was significantly attenuated by APC treatment. These results show that APC treatment for IRI in steatotic liver does not affect initial liver damage, but it may attenuate late damage, suggesting that APC might act through a pathway in addition to an anti-inflammatory cytoprotective effect. In previous reports, the presence of macrosteatosis significantly increased the incidence in primary graft dysfunction $[24,25]$ and decreased patient survival after orthotopic liver transplantation. Moreover, livers with macrovesicular fat deposition have lower tolerance to IRI compared with microsteatotic livers $[26,27]$. Our steatotic mice had significantly increased IRI, shown by higher transaminase levels and disrupted liver histology compared with nonsteatotic liver, although serum aminotransferase levels and liver histological outcomes were improved by APC treatment in both nonsteatotic and steatotic mice. Particularly when we focused on the time point of $24 \mathrm{~h}$, post-IRI livers of the steatotic mice showed prolonged parenchymal injury, compared with nonsteatotic mice whose liver injury was already settled down from IRI.

APC treatment in nonsteatotic liver prevented sinusoidal endothelial injury at $4 \mathrm{~h}$ and at $24 \mathrm{~h}$, as shown by the expression of PECAM-1 (which is a major constituent of the endothelial cell intercellular junctions and a negative regulator of inflammatory responses [28, 29]). However, APC treatment in steatotic liver did not show any effect on injury until $24 \mathrm{~h}$. APC provides a direct cytoprotective effect on sinusoidal endothelial cells through PAR1 signaling via EPCR-bound APC activation [11]. When we compared the structure of endothelial cells positively stained by PECAM1 between nonsteatotic and steatotic livers (as shown in 


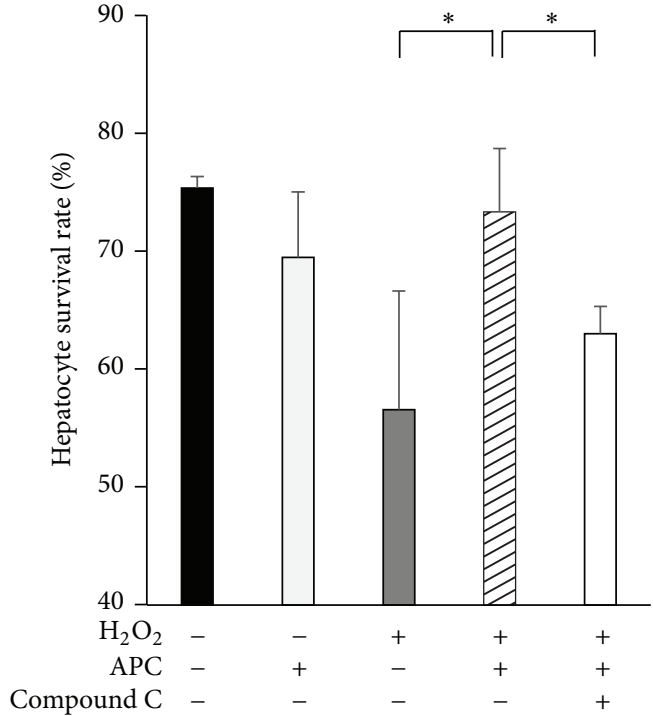

(a)

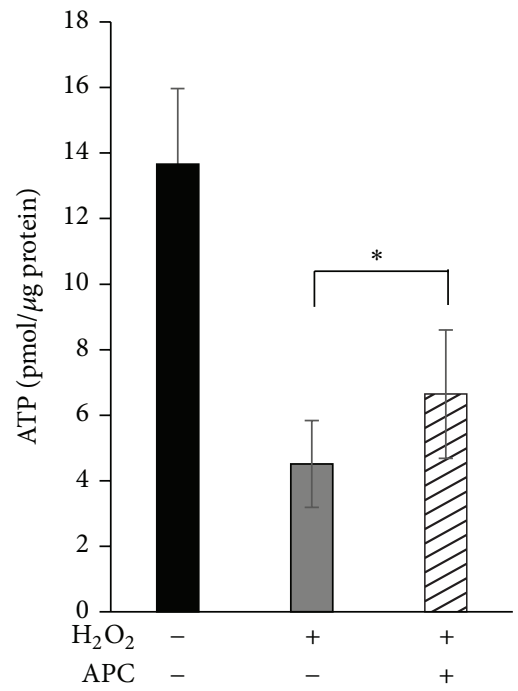

(c)

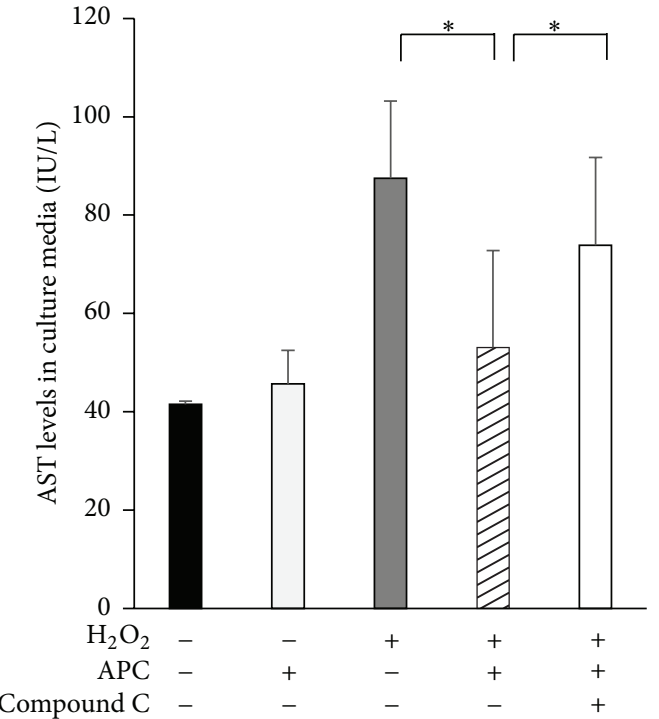

(b)
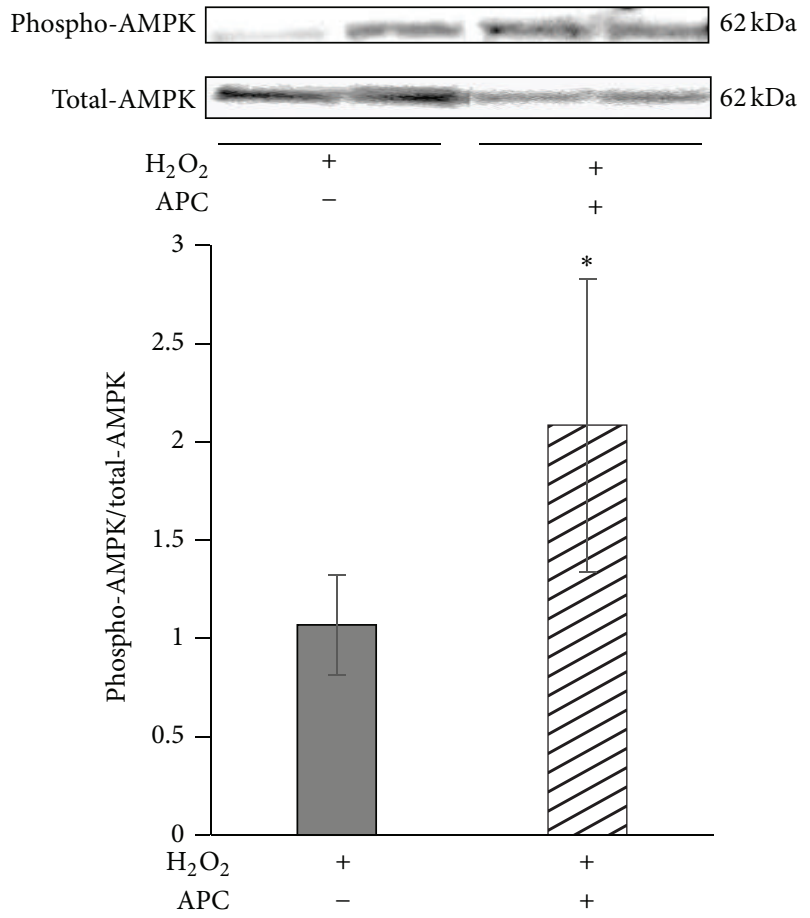

(d)

FIGURE 7: Direct effects of APC on steatotic hepatocytes in vitro. In cells treated with $\mathrm{H}_{2} \mathrm{O}_{2}+$ APC, the survival rates of steatotic hepatocytes were significantly increased compared with those of cells treated with $\mathrm{H}_{2} \mathrm{O}_{2}$ alone $\left({ }^{*} P<0.05\right.$ ). By adding an inhibitor of AMPK (compound C), the survival rate was significantly decreased $\left({ }^{*} \mathrm{P}<0.05\right)$ (a). Cell cytotoxicity, which was calculated by the AST level in the culture media, was significantly decreased in the $\mathrm{H}_{2} \mathrm{O}_{2}+\mathrm{APC}$ treatment, compared with $\mathrm{H}_{2} \mathrm{O}_{2}$ treatment alone. By adding compound C, the AST levels were significantly increased (b). APC increased the ATP concentration in hepatocytes which were cultured for $24 \mathrm{~h} \mathrm{with} \mathrm{H}_{2} \mathrm{O}_{2}$ (c). Representative western blots for phospho-AMPK (p-AMPK) and total-AMPK (t-AMPK) in hepatocytes which were cultured for $24 \mathrm{~h}$ with $\mathrm{H}_{2} \mathrm{O}_{2}$ are shown; APC increased AMPK phosphorylation $\left({ }^{*} P<0.05\right)(\mathrm{d})$.

Figures 4(a) and 4(c)), sinusoidal endothelial structures were severely disrupted regardless of the APC treatment in steatotic liver, while these structures in nonsteatotic liver were well preserved even in mice without APC treatment. Consequently, we propose that APC treatment could not exert a cytoprotective effect on endothelial vasculature in steatotic liver because it was too severely damaged.

Recently, Wang et al. demonstrated that APC strongly attenuated acute myocardial injury by activating AMPK, an effect that was largely independent of its anticoagulant 
function. This was shown in both in vivo and ex vivo mouse model systems: cardiomyocytes expressed EPCR and APC directly triggered AMPK phosphorylation in cardiomyocytes by enhancing the $\mathrm{Ca} 2+/ \mathrm{CaMKK} \beta$ activity by EPCR- and PAR1-dependent mechanisms [14]. AMPK activates ATPgenerating pathways and downregulates ATP-consuming anabolic pathways. We therefore focused on AMPK phosphorylation as a pathway additional to the anti-inflammatory cytoprotective effect of APC. In the present study, APC administration in steatotic liver enhanced its phosphorylation at $4 \mathrm{~h}$, but not at $24 \mathrm{~h}$. In contrast, in nonsteatotic liver, APC administration did not influence AMPK phosphorylation. Histologically, APC treatment did not attenuate liver damage at $4 \mathrm{~h}$, while it significantly reduced the percentage of liver necrosis at $24 \mathrm{~h}$. According to these results, we consider that APC might prevent ATP depletion at $4 \mathrm{~h}$ via activation of AMPK phosphorylation, which in turn might partly attenuate the necrosis at $24 \mathrm{~h}$ in I/R injury. In our in vitro study, which included a specific inhibitor of AMPK (compound C), the survival rates of steatotic hepatocytes were significantly increased when APC was added in the culture media, while steatotic hepatocyte survival rates were significantly decreased when compound $\mathrm{C}$ was added in the culture media containing APC. Nevertheless, in the in vivo study, APC administration significantly attenuated serum transaminase levels, liver histological damage, and leukocyte recruitment in nonsteatotic liver at $4 \mathrm{~h}$ and in steatotic liver at $24 \mathrm{~h}$. Therefore, we propose that the main pathway through which APC exerts its cytoprotective effect is the suppression of neutrophil recruitment, although we believe that APC might also exert cytoprotective effects via activation (phosphorylation) of AMPK in steatotic liver.

Target receptors of APC that might directly act on hepatocytes are still unknown. There have been several reports demonstrating that there are receptors of APC other than EPCR, such as the sphingosine-1-phosphate receptor 1 in intestinal epithelial cells [30] and lung epithelial cells [31], several integrins in macrophages [32], PAR3 in neural cells [33], and the apolipoprotein E receptor 2 in platelets [34]. Further study is required to elucidate which of these specific receptors could be the targets of APC in steatotic hepatocytes.

In conclusion, during IRI in normal liver, APC treatment attenuated initial liver damage by inhibiting inflammatory cells infiltration and sinusoidal endothelial injury, while under IRI in steatotic liver APC did not affect initial liver damage but attenuated late damage, suggesting the existence of a pathway additional to the anti-inflammatory cytoprotective effect of APC which may be via activation of AMPK.

\section{Conflict of Interests}

The authors declare that there is no conflict of interests regarding the publication of this paper.

\section{References}

[1] G. Vernon, A. Baranova, and Z. M. Younossi, "Systematic review: the epidemiology and natural history of non-alcoholic fatty liver disease and non-alcoholic steatohepatitis in adults,"
Alimentary Pharmacology and Therapeutics, vol. 34, no. 3, pp. 274-285, 2011.

[2] M. Hayashi, K. Fujii, T. Kiuchi et al., "Effects of fatty infiltration of the graft on the outcome of living-related liver transplantation," Transplantation Proceedings, vol. 31, no. 1-2, p. 403, 1999.

[3] R. Canelo, F. Braun, B. Sattler et al., "Is a fatty liver dangerous for transplantation?" Transplantation Proceedings, vol. 31, no. 12, pp. 414-415, 1999.

[4] K. E. Behrns, G. G. Tsiotos, N. F. DeSouza, M. K. Krishna, J. Ludwig, and D. M. Nagorney, "Hepatic steatosis as a potential risk factor for major hepatic resection," Journal of Gastrointestinal Surgery, vol. 2, no. 3, pp. 292-298, 1998.

[5] M. Selzner, H. A. Rüdiger, D. Sindram, J. Madden, and P.-A. Clavien, "Mechanisms of ischemic injury are different in the steatotic and normal rat liver," Hepatology, vol. 32, no. 6, pp. 1280-1288, 2000.

[6] A. M. Seifalian, V. Chidambaram, K. Rolles, and B. R. Davidson, "In vivo demonstration of impaired microcirculation in steatotic human liver grafts," Liver Transplantation and Surgery, vol. 4, no. 1, pp. 71-77, 1998.

[7] P. Caraceni, C. Bianchi, M. Domenicali et al., "Impairment of mitochondrial oxidative phosphorylation in rat fatty liver exposed to preservation-reperfusion injury," Journal of Hepatology, vol. 41, no. 1, pp. 82-88, 2004.

[8] K. S. Echtay, D. Roussel, J. St-Plerre et al., "Superoxide activates mitochondrial uncoupling proteins," Nature, vol. 415, no. 6867, pp. 96-99, 2002.

[9] A. Rashid, T.-C. Wu, C.-C. Huang et al., "Mitochondrial proteins that regulate apoptosis and necrosis are induced in mouse fatty liver," Hepatology, vol. 29, no. 4, pp. 1131-1138, 1999.

[10] Y. Yamaguchi, N. Hlsama, K. Okajima et al., "Pretreatment with activated protein $\mathrm{C}$ or active human urinary thrombomodulin attenuates the production of cytokine-induced neutrophil chemoattractant following ischemia/reperfusion in rat liver," Hepatology, vol. 25, no. 5, pp. 1136-1140, 1997.

[11] N. Kuriyama, S. Isaji, T. Hamada et al., "Activated protein C prevents hepatic ischaemia-reperfusion injury in rats," Liver International, vol. 29, no. 2, pp. 299-307, 2009.

[12] A. R. Rezaie, "Regulation of the protein C anticoagulant and antiinflammatory pathways," Current Medicinal Chemistry, vol. 17, no. 19, pp. 2059-2069, 2010.

[13] L. O. Mosnier, B. V. Zlokovic, and J. H. Griffin, "The cytoprotective protein C pathway," Blood, vol. 109, no. 8, pp. 3161-3172, 2007.

[14] J. Wang, L. Yang, A. R. Rezaie, and J. Li, "Activated protein $\mathrm{C}$ protects against myocardial ischemic/reperfusion injury through AMP-activated protein kinase signaling," Journal of Thrombosis and Haemostasis, vol. 9, no. 7, pp. 1308-1317, 2011.

[15] S. Yang, H. Zhu, Y. Li et al., "Mitochondrial adaptations to obesity-related oxidant stress," Archives of Biochemistry and Biophysics, vol. 378, no. 2, pp. 259-268, 2000.

[16] K. D. Chavin, S. Yang, H. Z. Lin et al., "Obesity induces expression of uncoupling protein-2 in hepatocytes and promotes liver ATP depletion," The Journal of Biological Chemistry, vol. 274, no. 9, pp. 5692-5700, 1999.

[17] T. Hamada, C. Fondevila, R. W. Busuttil, and A. J. Coito, "Metalloproteinase-9 deficiency protects against hepatic ischemia/reperfusion injury," Hepatology, vol. 47, no. 1, pp. 186-198, 2008

[18] H. Kato, N. Kuriyama, S. Duarte, P.-A. Clavien, R. W. Busuttil, and A. J. Coito, "MMP-9 deficiency shelters endothelial 
PECAM-1 expression and enhances regeneration of steatotic livers after ischemia and reperfusion injury," Journal of Hepatology, vol. 60, no. 5, pp. 1032-1039, 2014.

[19] S. Suzuki, L. H. Toledo-Pereyra, F. J. Rodriguez, and D. Cejalvo, "Neutrophil infiltration as an important factor in liver ischemia and reperfusion injury. Modulating effects of FK506 and cyclosporine," Transplantation, vol. 55, no. 6, pp. 1265-1272, 1993.

[20] S. W. C. Chen, S. W. Park, M. Kim, K. M. Brown, V. D. D’Agati, and H. T. Lee, "Human heat shock protein 27 overexpressing mice are protected against hepatic ischemia and reperfusion injury," Transplantation, vol. 87, no. 10, pp. 1478-1487, 2009.

[21] Z. Li, M. J. Soloski, and A. M. Diehl, "Dietary factors alter hepatic innate immune system in mice with nonalcoholic fatty liver disease," Hepatology, vol. 42, no. 4, pp. 880-885, 2005.

[22] D. G. Hardie, D. Carling, and M. Carlson, "The AMPactivated/SNF1 protein kinase subfamily: metabolic sensors of the eukaryotic cell?" Annual Review of Biochemistry, vol. 67, pp. 821-855, 1998.

[23] R. Costa, A. Morrison, J. Wang, C. Manithody, J. Li, and A. R. Rezaie, "Activated protein C modulates cardiac metabolism and augments autophagy in the ischemic heart," Journal of Thrombosis and Haemostasis, vol. 10, no. 9, pp. 1736-1744, 2012.

[24] A. K. K. Chui, K. Haghighi, D. Painter et al., "Donor fatty (steatotic) liver allografts in orthotopic liver transplantation," Transplantation Proceedings, vol. 30, no. 7, pp. 3286-3287, 1998.

[25] S. M. Strasberg, T. K. Howard, E. P. Molmenti, and M. Hertl, "Selecting the donor liver: risk factors for poor function after orthotopic liver transplantation," Hepatology, vol. 20, no. 4, pp. 829-838, 1994.

[26] N. Selzner, M. Selzner, W. Jochum, B. Amann-Vesti, R. Graf, and P.-A. Clavien, "Mouse livers with macrosteatosis are more susceptible to normothermic ischemic injury than those with microsteatosis," Journal of Hepatology, vol. 44, no. 4, pp. 694701, 2006.

[27] D. J. Verran, T. Kusyk, D. Painter et al., "Clinical experience gained from the use of 120 steatotic donor livers for orthotopic liver transplantation," Liver Transplantation, vol. 9, no. 5, pp. 500-505, 2003.

[28] R. Goel, B. Boylan, L. Gruman, P. J. Newman, P. E. North, and D. K. Newman, "The proinflammatory phenotype of PECAM-1deficient mice results in atherogenic diet-induced steatohepatitis," The American Journal of Physiology-Gastrointestinal and Liver Physiology, vol. 293, no. 6, pp. G1205-G1214, 2007.

[29] P. J. Newman, “The biology of PECAM-1," The Journal of Clinical Investigation, vol. 99, no. 1, pp. 3-8, 1997.

[30] J. Greenspon, R. Li, L. Xiao et al., "Sphingosine-1-phosphate regulates the expression of adherens junction protein E-cadherin and enhances intestinal epithelial cell barrier function," Digestive Diseases and Sciences, vol. 56, no. 5, pp. 1342-1353, 2011.

[31] J. H. Finigan, S. M. Dudek, P. A. Singleton et al., "Activated protein $\mathrm{C}$ mediates novel lung endothelial barrier enhancement: role of sphingosine 1-phosphate receptor transactivation," The Journal of Biological Chemistry, vol. 280, no. 17, pp. 17286-17293, 2005.

[32] C. Cao, Y. Gao, Y. Li, T. M. Antalis, F. J. Castellino, and L. Zhang, "The efficacy of activated protein $\mathrm{C}$ in murine endotoxemia is dependent on integrin CD11b," The Journal of Clinical Investigation, vol. 120, no. 6, pp. 1971-1980, 2010.

[33] H. Guo, D. Liu, H. Gelbard et al., "Activated protein C prevents neuronal apoptosis via protease activated receptors 1 and 3," Neuron, vol. 41, no. 4, pp. 563-572, 2004.
[34] T. C. White, M. A. Berny, E. I. Tucker et al., "Protein C supports platelet binding and activation under flow: role of glycoprotein Ib and apolipoprotein E receptor 2," Journal of Thrombosis and Haemostasis, vol. 6, no. 6, pp. 995-1002, 2008. 


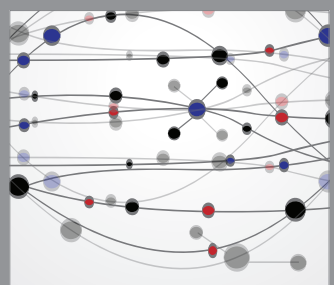

The Scientific World Journal
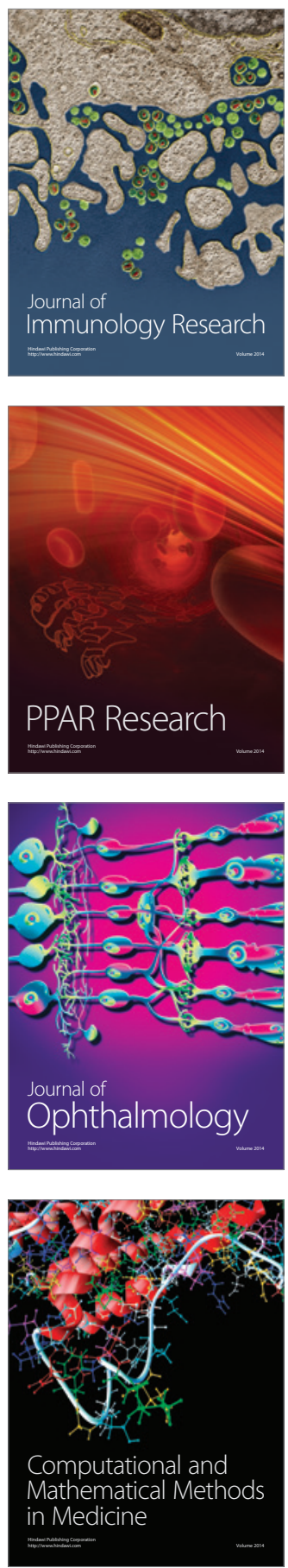

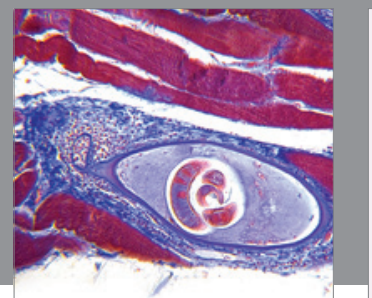

Gastroenterology

Research and Practice
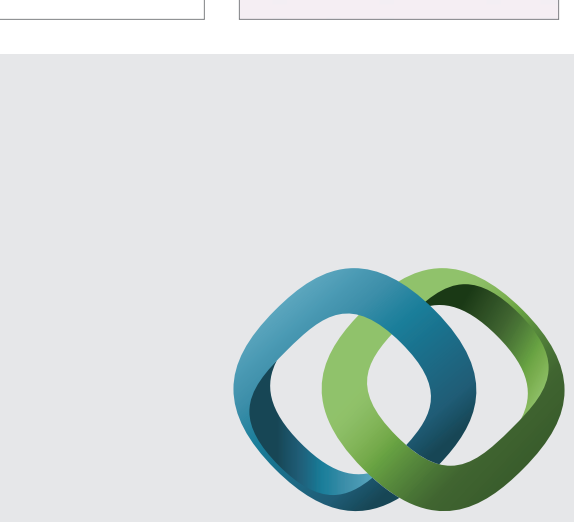

\section{Hindawi}

Submit your manuscripts at

http://www.hindawi.com
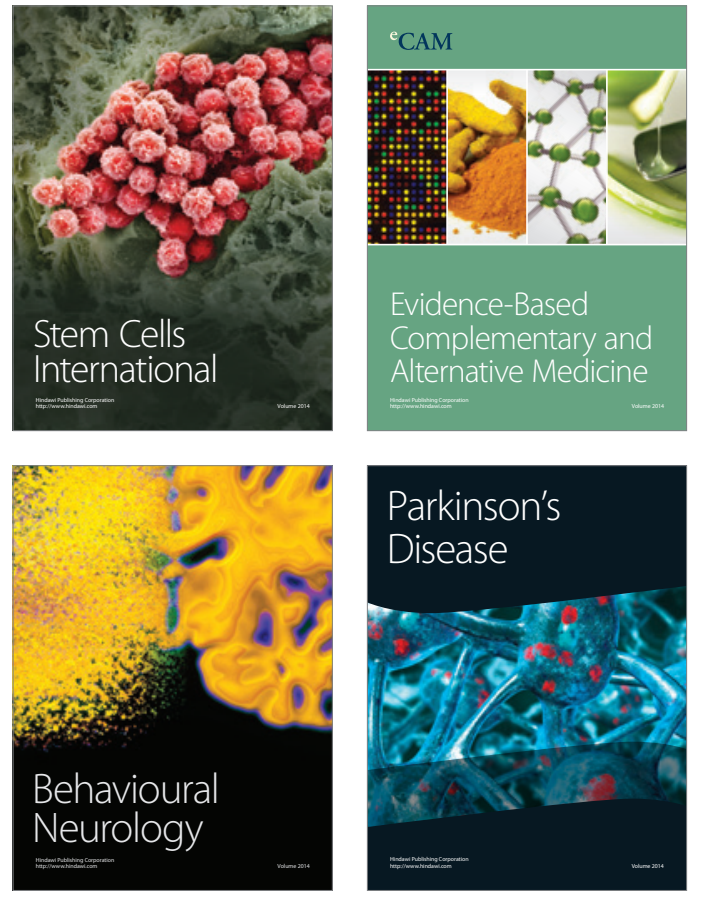
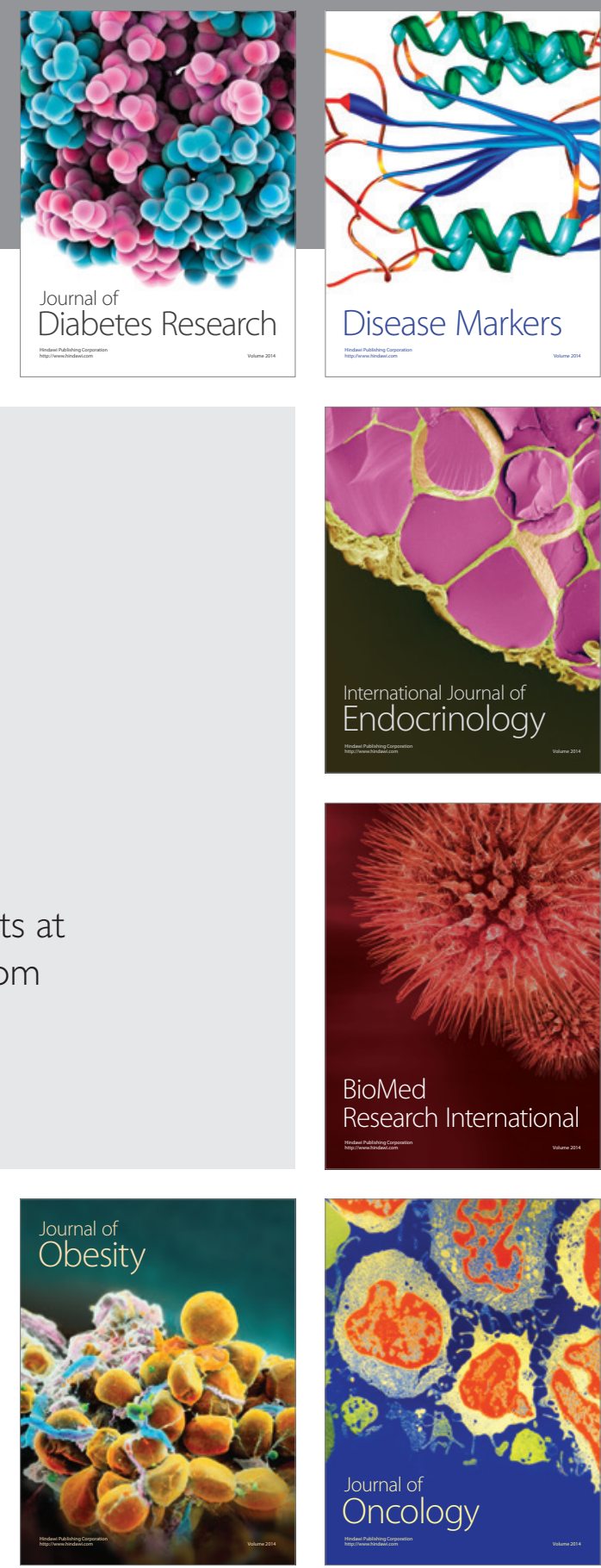

Disease Markers
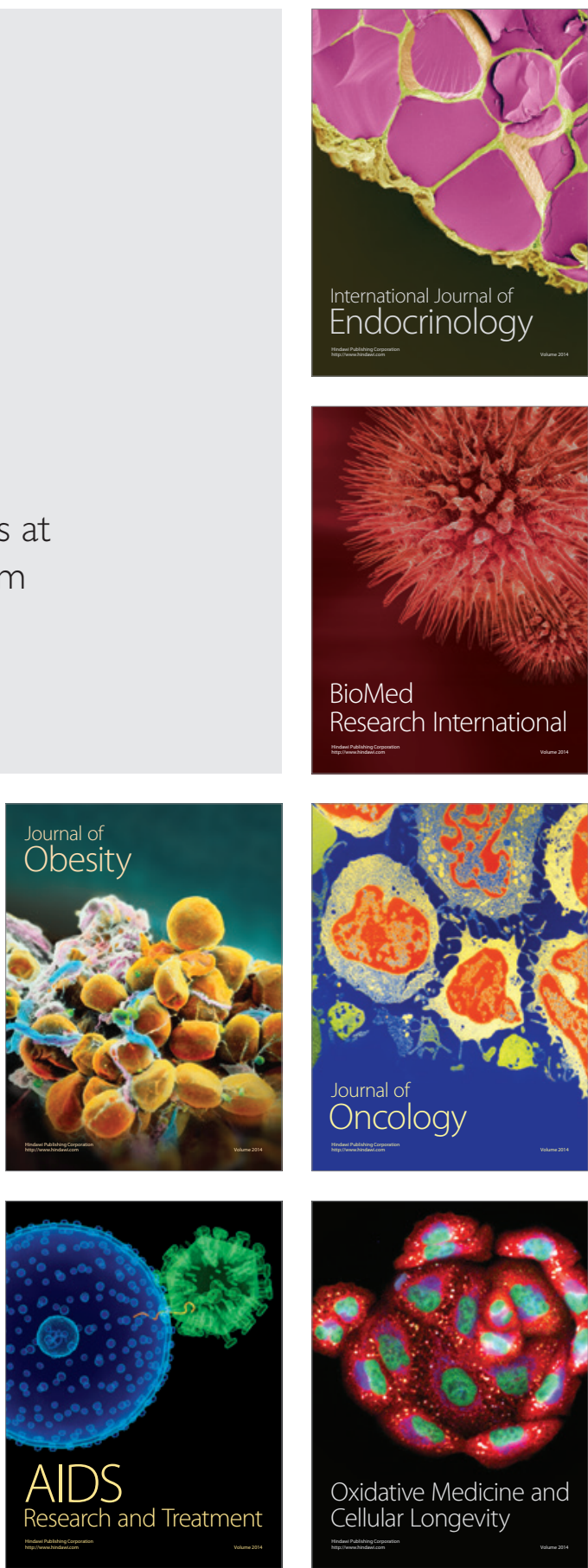